\title{
Demiryollarının Konteyner Limanı-Hinterlant Bağlantılarındaki Önemi: Mersin Limanı Örneği
}

\author{
Hulya ZEYBEK (D)
}

Eskişehir Teknik Üniversitesi, Ulaştırma Meslek Yüksek Okulu, Eskişehir, Türkiye

\author{
hulyazeybek@eskisehir.edu.tr
}

(Alınış/Received: 14.12.2020, Kabul/Accepted: 14.03.2021, Yayımlama/Published: 31.07.2021)

\begin{abstract}
Öz: Konteynerlerin kullanımı ile deniz taşımacılığı yaygınlaşmış ve uluslararası ticarette en çok kullanılan taşımacılık türü haline gelmiştir. Konteynerlerin, deniz taşımacılı̆̆ının ana altyapısını oluşturan limanlardan hinterlanda taşınması, taşıma zincirindeki en zayıf halkayı oluşturmaktadır. Ayrıca, hinterlant bağlantı maliyetlerinin uluslararası yük taşıma zincirinin en yüksek maliyet kalemini oluşturması, bu bağlantıların önemini daha da arttırmaktadır. Bu çalışmada, demiryollarının konteyner limanlarının hinterlant bağlantılarındaki önemi incelenmiş, liman hinterlandında demiryolu taşımacıllğının gelişmesine yönelik güçlü ve zayıf yönler ile firsat ve tehditleri tespit etmek amacıyla Mersin Limanı örnek alınarak bir SWOT analizi yapılmıştır. Çalışma sonuçları, Mersin Limanı'nın demiryolu hinterlant bağlantısının güçlendirilmesine ihtiyaç olduğunu ve bunun için de paydaşlar arasında iş birliği ve entegrasyonun sağlanmasının önemini ortaya koymaktadır.
\end{abstract}

Anahtar kelimeler: Liman hinterlant bağlantısı, Demiryolu konteyner taşımacılığı, Mersin limanı, Dış ticaret

\section{The Importance of Railways for Hinterland Connections of Container Ports: The Case of Mersin Port}

Abstract: With the use of containers, maritime transport has rapidly widespread and has become the most preferred transport mode in international trade. The transport of containers from seaports -the main infrastructure of maritime transport- to the hinterlands constitutes the weakest link of the transport chain. The fact that hinterland connection costs constitute the highest cost item of the international freight transport chain further increases the importance of these connections. In this study, the importance of railways for the hinterland connections of container ports was analyzed and a SWOT analysis was conducted to reveal the strengths and weaknesses, opportunities, and threats for the development of rail transport in the port hinterlands by taking the Mersin Port as a case. The results of the study reveal the need for strengthening the railway hinterland connection of Mersin Port and the importance of ensuring cooperation and integration among stakeholders for this.

Keywords: Port hinterland connections, Railway container transport, Mersin port, International trade

\section{Giriş}

Konteynerlerin kullanılmaya başlanmasından sonra denizyolu taşımacılığında maliyetlerin düşmesi ve verimliliğin artması ile dünya ticaretinde denizyolu taşımacılığı yaygınlaşmış ve küresel ticaretin yaklaşık \%90'ı denizyolu ile yapılır hale gelmiştir. Bu taşımanın büyük bir kısmı da konteyner gemileri ile yapılmaktadır [1]. Avrupa ile Asya arasındaki ticaretin miktar olarak yaklaşık \%90'1, değer olarak da \%60'ı denizyolu ile gerçekleştirilmektedir [2]. 2019 yılı sonu değerlerine göre Türkiye'nin dış ticaretinin miktar olarak \%88,6's1, değer olarak \%57'si denizyoluyla gerçekleştirilmiştir [3]. Denizyolu taşımacılığının temel altyapısını oluşturan limanlar, deniz ve kara arasındaki bağlantıyı sağlamakta, bir tarafinda denizcilik şirketleri, diğer tarafında da hinterlant taşımacılık şirketleri bulunmaktadır [4]. Dünya ve Türkiye ticaretinin 
büyük bir kısmının denizyolu ile gerçekleştirilmesi limanların ve hinterlant bağlantılarının önemini artırmaktadır.

Genelde, liman yönetimleri liman kapasitesinin arttırılması ve liman altyapısının iyileştirilmesi gibi liman alanı içindeki yatırımlara odaklanmakla beraber son yıllarda bazı liman otoriteleri, tedarik zinciri perspektifi ile liman alanı dışında da aktif rol oynamaya ve liman-hinterlant bağlantılarına katkıda bulunmaya başlamışlardır [5]. Özellikle, hinterlant bağlantı maliyetlerinin uluslararası yük taşıma zincirinin en yüksek maliyet kalemini oluşturması, bu bağlantıların iyileştirilmesinin önemini arttırmıştır [6]. Konteynerlerin limandan hinterlanda taşınması, taşıma zincirindeki en zayıf halkayı oluşturmaktadır.

Liman hinterlant bağlantıları ile ilgili yabancı literatürde çeşitli araştırmalar bulunmaktadır. Carbone ve De Martino [4] Renault'nun tedarik zincirini dikkate alarak limanların değişen rolüne ilişkin Le Havre limanında ampirik bir çalışma yapmıştır. Van den Berg ve De Langen [5] ise Barselona örneğinde liman otoritelerinin hinterlant stratejilerini incelemiştir. Halim vd. [6] limanhinterlant yük dağıtımı ağ için stratejik bir model önerisinde bulunmuştur. Notteboom ve Rodrigue [7] liman hinterlandını makro-ekonomik hinterlant, fiziksel hinterlant ve lojistik hinterlant olarak sınıflandırmıştır. Bu sınıflandırmayı baz alarak Shi ve Li [8] Çin'deki Shenzhen Limanı'nın hinterlandının gelişimini analiz etmiştir. Bucak ve Esmer [9] çalışmalarında liman hinterlant performansının bileşenlerini belirlemek amacıyla literatür taraması yaparak çalışmalarda kullanılan yöntemleri belirlemiştir.

Türkiye'deki hinterlant çalışmaları daha çok lojistik köyler üzerinde yoğunlaşmaktadır. Özdemir vd. [10] tarafindan yapılan çalışmada, lojistik merkezlerin değerlendirilmesi için yeni bir yöntem önerilmiştir. Bayhan vd [11] Denizli'de kurulmuş olan Kaklık Lojistik Köyünün SWOT analiziyle değerlendirmesini yapmıştır. İrtem [12] dünya limanlarının "Hinterlant Bağlanabilirlik" yetenekleri ve bu konuda yaptıkları yatırımlar üzerine yapılan çalışmalarını inceleyerek Batı Akdeniz Bölge Hinterlandında navlun trafiğinin kalitesini artıracak bir çözüm yolu olarak ticaret limanın kapısının Bucak Ovasına çekilmesini tartışmıştır. Bazı çalışmalarda hinterlant terimi etki alanı olarak ele alınmış ve limanların etki alanları incelenmiştir [13].

Uluslararası konteyner taşımacılığında liman-hinterlant bağlantılarının ulaşım maliyetleri açısından önemine karşın Türkiye'de konteyner limanlarının demiryolu hinterlant bağlantılarına ilişkin yeterli çalışmanın yapılmamış olduğu görülmektedir. Bu çalışmada, tedarik zinciri yaklaşımı ile konteyner limanlarının demiryolu hinterlant bağlantılarının geliştirilme potansiyeli, Mersin Limanı örnek alınarak incelenmiştir. Mersin Limanı'nın seçilmesinin nedeni, Türkiye'nin uluslararası lojistik üs niteliğindeki en önemli konteyner limanlarından biri olması ve Türkiye'deki diğer konteyner limanlarına göre demiryolu bağlantısı açısından daha avantajlı bir konumda [14] bulunmasidır.

\section{Konteyner Limanlarının Demiryolu Hinterlant Bağlantıları ve Önemi}

Uluslararası ticaretin artmasıyla beraber küresel tedarik zincirlerinin gelişimi hızlanmış, bu gelişme deniz taşımacılığına, liman operasyonlarına ve liman-hinterlant bağlantılarına yönelik baskıyı arttırmıştır. Hızla değişen müşteri beklentilerine kendini adapte etmek isteyen limanlar, tedarik zincirinin tümüne yönelerek katma değerli hizmet sunmaya başlamış, dağıtım ve lojistik merkezlerine dönüşme sürecine girmiştir [15]. Böylece, deniz ulaşım hizmetleri kapıdan kapıya intermodal taşımacılığın bir parçası haline gelmiştir [16]. Nitekim, Rodrigue ve Notteboom [17], limanları tedarik zincirinin bir parçası olarak yeniden tanımlamış ve bu zincirde rekabeti etkileyen temel faktör olarak hinterlant bağlantılarının önemini vurgulamışlardır. 
Hinterlant bağlantılarının kalitesi, limanların gelişmesi ve rekabet gücünün artmasında önemli rol oynamaktadırlar. Uluslararası ticarette liman-hinterlant bağlantılarının önem kazanmasının en önemli nedeni, hinterlant dağıtım maliyetinin toplam maliyetler içindeki payıdır. Hinterlanda taşıma mesafesi taşımacılık zincirinin sadece \%10'unu oluşturmasına rağmen hinterlant taşıma maliyetinin toplam taşımacılık maliyeti içindeki payı yaklaşık \%80'dir [18]. Dolayısıyla, limanhinterlant ulaşım maliyetleri uluslararası yük taşıma zincirinin en yüksek maliyet kalemini oluşturmaktadır [19]. Bu nedenle, hinterlant bağlantıları, toplam maliyetlerin azaltılmasında önemli bir faktör olarak dikkate alınmaktadır [20]. Ayrıca, liman-hinterlant dağıtım sistemlerindeki bağlantılar müşterilerin liman seçiminde de önemli rol oynamaktadır [21].

Bir limanın hinterlandını, limana gelen yükün geldiği alan ya da çıkış noktası veya limanda boşaltılan yükün gittiği yer ya da varış noktası belirlemektedir [22]. Ferrari vd. [23] liman hinterlandını "liman faaliyetlerinin büyük kısmını üreten geri saha" olarak tanımlamaktadır. Ancak, liman hinterlandı oldukça dinamik yapıdadır ve zaman içinde ekonomik gelişmeler, mevsimsel değişim, teknolojik gelişmeler, müşterilerin ve lojistik şirketlerin stratejilerindeki ve ulaşım politikalarındaki değişim gibi faktörlerin etkisiyle değişebilir. Limanlar hinterlanda demiryolu ve karayolu ile bağlanmaktadır. Bu sistemlerin gelişmişliği ve kapasiteleri liman faaliyetlerini etkilemektedir. Son yıllarda, limanların hinterlanda demiryolu ile bağlanması konusunda önemli çalışmalar yapılmaktadır.

Liman-hinterlant taşımalarının performansında demiryolunun rolü oldukça önemlidir [24]. Asya ülkelerinden gelen yük akışını çekmek için rekabet eden limanlar, ekonomik ve çevresel nedenlerle, liman hinterlandına demiryolu bağlantısı kurmaya ve geliştirmeye yönelik önemli yatırımlar yapmaktadırlar. Liman-hinterlant bağlantılarında demiryolu kullanımının arttığ örnekler çeşitlidir. Örneğin, Almanya'da Hamburg ve Bremerhaven limanları hinterlant taşımalarında demiryolu ile konteyner sevkiyatını arttırmıştır. Bu limanlardan hinterlanda taşımalardaki demiryolunun payı diğer büyük Avrupa limanlarına göre oldukça yüksektir [25]. Hamburg Limanı ile liman hinterlandı arasında günde yaklaşık 200 yük treni düzenli çalışmaktadır. Hinterlanda taşımalarda demiryolu kullanımı \%30'u aşmıştır. Bremenhaven Limanı'nda ise hinterlant taşımalarında demiryolu kullanımı oranı \% 45 'lere ulaşmaktadır. Bu gelişmede, liman-hinterlant bağlantılarında mekik trenlerin (iki terminal arasında sabit vagon adedi ile çalışan trenler) kullanılması ve entegre fiyat (nakliye, kara terminalinde elleçleme ve dağıtım bedelini de içeren fiyat) uygulaması gibi stratejiler önemli rol oynamıştır [24].

Avrupa'nın büyük konteyner limanlarından biri olan İsveç'in Göteborg Limanı da demiryolu ile hinterlant taşımalarını arttırmakta başarılı olmuş ve demiryolunun payı 2011 yılında \%40'a ulaşmıştır. 2019 yılında limandan demiryolu ile 456.000 TEU (20 feet'lik konteyneri ifade etmektedir) konteyner taşıması yapılarak rekor kırılmıştır [26]. Bu başarıda işbirlikçi bir yönetim sistemi, kamu yatırımları ve müşteri taleplerinin karşılanması önemli rol oynamıştır [24]. Woodburn [27]'un İngiltere ekonomisi özelinde yaptığı araştırma sonuçları liman konteyner taşımalarında artış yaşandığını, 2007 yılında \%14,7 olan demiryolu payının 2015 yılında \%16,6'ya çıktığını ortaya koymuştur. Rotterdam limanına gelen konteynerlerin \%10,4'ü (760.000 konteyner) demiryolu ile hinterlanda taşınmaktadır. Rotterdam Limanından Almanya sınırına kadar uzanan $160 \mathrm{~km}$ uzunluğundaki BETUWE demiryolu yük hattında günde yaklaşı 100 tren çalışmaktadır [28]. Barselona Limanı ise daha fazla trafiği limana çekmek amacıyla tedarik zincirinde yeni rol üstlenerek hinterlant bağlantılarının güçlendirilmesine odaklanmış ve demiryolu bağlantılarının geliştirilmesinde aktif rol almıştır. Bu kapsamda, ilk aşamada, hinterlandında stratejik yerlerde bulunan demiryolu tesislerine ortak olmuştur. İkinci aşamada da konteyner depoları, demiryolu terminalleri (örneğin, Zaragoza demiryolu terminali) ve lojistik merkezlere; üçüncü aşamada ise mekik trenlere yatırım yapılmıştır [5]. Uygulanan bu stratejiler sonucunda Barcelona limanından hinterlanda taşımalarda demiryolu payı 2007 y1lında \%2,6 iken 2016 yılında \%12,5’e çıkmıştır [29]. 
Öte yandan, "Kuşak ve Yol Girişimi-BRI” kapsamında Çin'in denizcilik şirketi COSCO, işletme hakkını aldığı Pire Limanı'na demiryolu bağlantısı kurmuş ve Yunan Demiryolu Taşıma Şirketi TrainOSE ile iş birliği içinde Çin mallarını Pire Limanı'ndan blok tren seferleri ile Orta Avrupa'ya ulaştırmaya başlamışıtır [30]. Hewlett Packard, Hyundai, Sony gibi çokuluslu şirketler ürünlerini Çekya, Slovakya ve Macaristan'daki fabrikalarına göndermek amacıyla Pire Limanı'nda lojistik merkezler kurmuşlardır [31].

Çin limanlarında demiryolunun pazar payı \%10'un altında olmasına rağmen, demiryolu işleticileri demiryolu yük taşımalarını arttırmak için limanlarla iş birliğine gitmeyi planlamaktadırlar [32].

Türkiye'de 2013 yılında başlatılan demiryollarında serbestleştirme ile artan beklentiler, limanları yeni döneme ayak uydurmaya ve özellikle 2017 yılında faaliyete geçen Bakü-Tiflis-Kars (BTK) demiryolu hattından gelecek yüklerin limanlara çekilebilmesi liman yönetimlerini demiryoluna yönelmeyi zorlamaktadır.

\section{Mersin Limanı}

Türkiye'nin güneyindeki en büyük konteyner limanlarından biri olan Mersin Limanı, bölgenin geniş endüstriyel hinterlandına hizmet vermektedir. Düzenli uğrak yapan 20'nin üzerinde konteyner hattıyla, dünyanın tüm ana limanlarıyla bağlantılıdır.

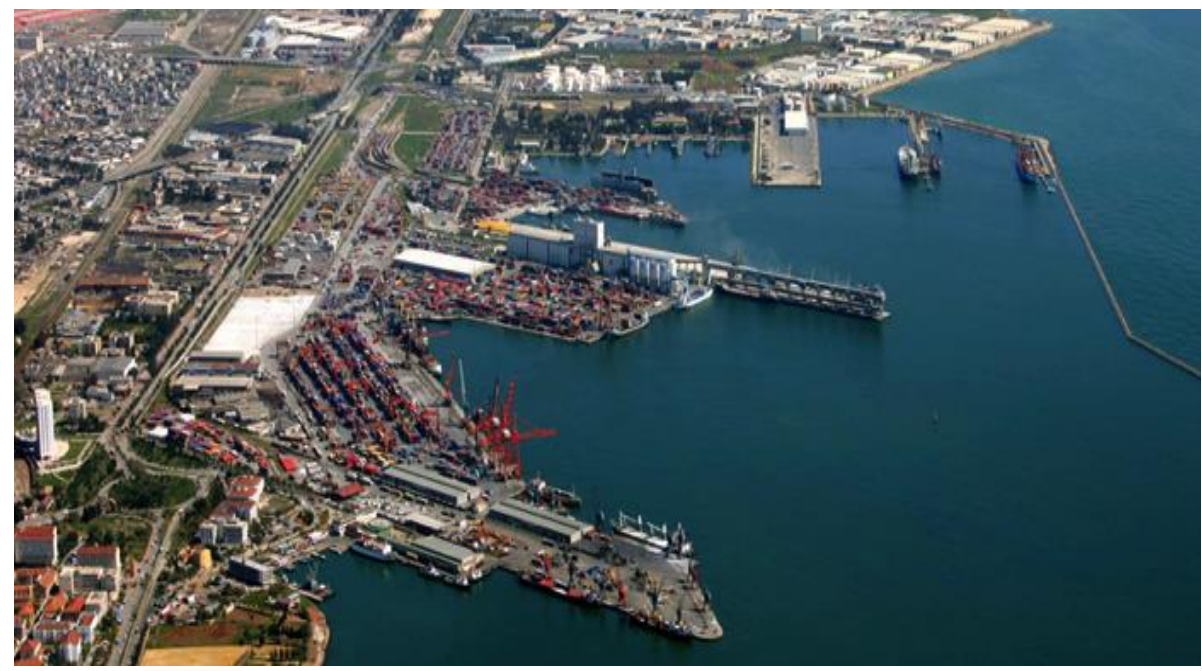

Şekil 1. Mersin limanı [33]

Mersin Limanı'nda, yılda yaklaşık 1.500 konteyner gemisine yükleme, tahliye, tekrar sevk ve/veya kabotaj hizmeti verilmektedir. Toplam 1.485 metre rihtım uzunluğu ve 15 metre derinliğe sahip konteyner terminalinde kesintisiz hizmet verilmektedir.

Tablo 1. Mersin limanı konteyner terminali teknik özellikleri [34]

\begin{tabular}{ll}
\hline Kapasite & 2,6 milyon TEU \\
Konteyner Rıhtımları & 9 adet \\
Azami Gemi Kabul Kapasitesi & 18.000 TEU \\
Gantry Vinç 40-65 ton & 11 adet \\
Mobil Vinç (MHC) 100-150 ton & 5 adet \\
Pilotaj-Römorkör-Palamar Servisleri & $7 / 24$ saat \\
\hline
\end{tabular}


Mersin Limanı'nda 2019 yılında 36,4 milyon ton yük elleçlenmiş, bunun 15,8 milyon tonu ihracat, 19 milyon tonu ithalat, 0,5 milyon tonu transit niteliğindedir. Konteyner elleçlemesinin payı ise \% 58 civarındadır [35]. Bu rakamlar Mersin Limanının bir aktarma limanı değil, bir dış ticaret limanı olarak hizmet vermekte olduğunu, Türkiye'nin dış ticaretine büyük katkı sağladığını göstermektedir.

Türkiye genelinde limanlarda 2019 yılında elleçlenen 11.591.838 TEU yükün \%39,6'sını ihracat, \%39,2'sini ithalat, \%14,7'sini de transit yükler oluşturmaktadır [3]. Mersin Limanı'nın konteyner elleçlemelerindeki Türkiye'deki durumu Şekil 2'de verilmiştir. Mersin limanı Türkiye'nin Ambarlı'dan sonra en fazla konteyner elleçlenen limanı konumundadır.

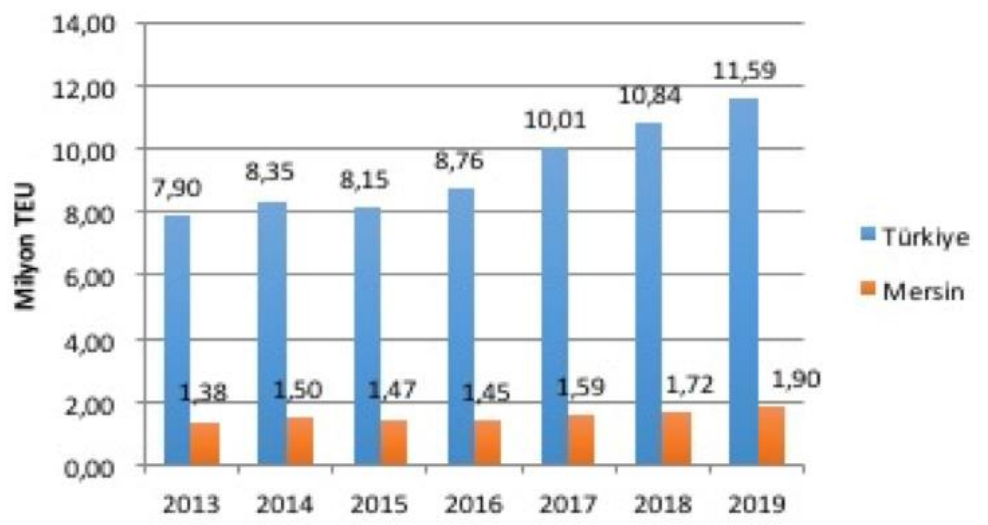

Şekil 2. Yıllara göre Türkiye limanları ve Mersin Limanı konteyner elleçlemeleri (milyon TEU) [35]

2020 yılının en büyük küresel 100 limanı sıralamasında Ambarlı Limanı 55. sırada, Mersin Limanı ise 92. sırada yer almaktadır [36]. Ambarlı'da 2019 yılında bir önceki yıla göre konteyner trafik hacminde düşüş olmuş, Mersin Limanında ise ekonomik krize rağmen artış yaşanmıştır.

\section{Metot}

Çalışmada çeşitli kaynaklardan literatür taraması yapılmış ve SWOT analizi yöntemi kullanılmıştır. SWOT analizi, stratejik kararları desteklemek için iç ve dış çevrenin analizinde yaygın olarak kullanılan bir tekniktir [37]. Bu teknikte, iç ve dış çevre etkenleri üstünlükler (güçlü yönler), zayıflıklar, firsatlar ve tehditler olarak dört grupta sınıflandırılmaktadır. Bu çalışmada SWOT analizi iç ve dış çevre etkenleri literatür incelemesi ve liman ve lojistik sektör uzmanlarının görüşleri alınarak belirlenmiştir. Yapılan analiz ile Türkiye'deki diğer limanlara göre demiryolu bağlantısı açısından daha avantajlı bir konumda olan Mersin Limanı'nın demiryolu hinterlant bağlantılarının geliştirilme potansiyeli değerlendirilmiş, üstünlükleri ve zayıflıkları belirlenmiş, ve geleceğe yönelik firsatlar ve tehditler ortaya konulmaya çalışılmıştır. Ayrıca, liman-demiryolu hinterlant bağlantılarının bölgeye ve ülkeye yapacağı ekonomik katkılar ele alınmış, özellikle dış ticarete etkisine dikkat çekilerek geleceğe yönelik tavsiyelerde bulunulmuştur.

\section{Bulgular}

Liman-demiryolu hinterlant bağlantıları açısından Mersin Limanı'nın SWOT Analizi sonucunda elde edilen bulgular Tablo 2'de verilmektedir.

\subsection{Güçlü yönler}


Mersin Limanı'nın demiryolu hinterlant bağlantılarının geliştirilmesine yönelik çeşitli olumlu ve güçlü unsurlar bulunmaktadır.

Türkiye'nin uluslararası lojistik üs niteliğindeki en önemli limanlarından biri olması; Mersin Limanı genel kargo, konteyner, Ro-Ro, kuru ve sıvı dökme yük ve yolcu gemilerine hizmet veren Türkiye'nin çok amaçlı en büyük limanı; Ambarlı'dan sonra en fazla konteyner elleçlenen limanıdır [3]. Mersin Limanı'nda 2019 yılında Türkiye genelinde yapılan toplam konteyner elleçlemesinin TEU olarak \%16'sı, ton olarak \%17,9'u gerçekleşmiştir [35]. Liman, İran, Irak gibi Orta Doğu Ülkeleri ve Türkiye Cumhuriyetler için transit merkez, Doğu ve Güneydoğu Anadolu, Akdeniz ve İç Anadolu Bölgelerinin ihracat ve ithalat kapısı konumundadır [38]. Transit bölge olarak Irak ve Suriye'ye, Kafkaslarda Azerbaycan, Orta Asya'da Kazakistan'a da hizmet vermektedir. Türkiye'nin demiryolu bağlantılı en büyük limanlarındandır.

Tablo 2. Mersin Limanı demiryolu hinterlant bağlantıları SWOT analizi

\begin{tabular}{|c|c|}
\hline Güçlü yönler & Zayıf yönler \\
\hline $\begin{array}{l}\text { Türkiye’nin uluslararası lojistik üs niteliğindeki en } \\
\text { önemli konteyner limanlarından biri olması }\end{array}$ & $\begin{array}{l}\text { Mersin Limanı'ndan hinterlanda taşımaların } \\
\text { karayolu ağırlıklı olması, demiryolu kullanımının } \\
\text { yetersiz kalması }\end{array}$ \\
\hline $\begin{array}{l}\text { Limana demiryolu bağlantısı ve liman içi } \\
\text { demiryolu altyapısının olması }\end{array}$ & $\begin{array}{l}\text { Demiryolu ve liman altyapı yatırımlarındaki } \\
\text { yetersizlik ve koordinasyonsuzluk }\end{array}$ \\
\hline Geniş bir hinterlanda sahip olması & $\begin{array}{l}\text { Mersin Limanı ile demiryolu ve lojistik şirketler } \\
\text { arasında yetersiz iş birliği ve entegrasyon }\end{array}$ \\
\hline $\begin{array}{l}\text { Demiryolu ağına göre geniş bir etki alanına sahip } \\
\text { olması }\end{array}$ & $\begin{array}{l}\text { Demiryolu ve liman altyapı yatırımlarında } \\
\text { yetersizlik ve koordinasyonsuzluk }\end{array}$ \\
\hline $\begin{array}{l}\text { Liman sahası içerisinde demiryolu terminalinin } \\
\text { olması }\end{array}$ & Yetersiz dijitalleşme \\
\hline Limana bitişik bir serbest bölgenin bulunması & Liman içi yük elleçlemede rekabetin olmaması \\
\hline $\begin{array}{l}\text { Küresel terminal operatörü PSA tarafindan } \\
\text { işletilmesi }\end{array}$ & İstatistiklerin yetersizliği \\
\hline Firsatlar & Tehditler \\
\hline Doğu Akdeniz'den geçen konteyner trafiği & Bölgedeki güçlü rakip limanlar \\
\hline $\begin{array}{l}\text { Kuşak ve Yol Girişimi ile demiryollarının ve } \\
\text { limanların desteklenmesi }\end{array}$ & $\begin{array}{l}\text { Kuşak ve Yol Girişimi ile rakip limanların } \\
\text { desteklenmesi }\end{array}$ \\
\hline $\begin{array}{l}\text { Orta Koridorun gelişmesi ve Bakü-Tiflis-Kars } \\
\text { demiryolu hattının açılması }\end{array}$ & Küresel ekonomik krizler-COVID-19 Salgını \\
\hline $\begin{array}{l}\text { Mersin Limanı hinterlandında demiryolu } \\
\text { yatırımlarının devam etmesi }\end{array}$ & $\begin{array}{l}\text { Müşterilerin demiryolu kalite algısının düşük } \\
\text { olması }\end{array}$ \\
\hline $\begin{array}{l}\text { Mersin Limanı yakınında Yenice'de lojistik merkez } \\
\text { kurulması }\end{array}$ & Dijital lojistik ve akıllı limanlara yönelim \\
\hline Demiryollarının serbestleştirilmesi & Bölgedeki politik ve güvenlik sorunları \\
\hline $\begin{array}{l}\text { Mersin Liman Yönetiminin liman sahası içindeki } \\
\text { demiryolu hattını büyütme hedefi }\end{array}$ & Nitelikli insan kaynağı ihtiyacı \\
\hline Sürdürülebilir taşımacılık stratejileri & Gümrüklerdeki sorunlar \\
\hline
\end{tabular}

Limana demiryolu bağlantısı ve liman içi demiryolu altyapısının olması; Türkiye'de demiryolu bağlantılarının büyük çoğunluğu devletin inşa etmiş olduğu limanlarda bulunmaktadır. Bağlantıların etkin olarak kullanıldığı ve demiryolu ile taşınan yükün kritik rol oynadığ liman sayısı oldukça sınırlıdır. Özel sektör tarafından inşa edilmiş limanların çok azında demiryolu 
bağlantısı ve liman içi demiryolu altyapısı mevcuttur. Mersin Limanı demiryolunu uzun süredir çok etkin olarak kullanan bir liman konumundadır.

Mersin Limanı'na 250 metre demiryolu hat bağlantısı, Liman içinde de $31 \mathrm{~km}$ demiryolu ile 51 adet makas bulunmaktadır. Ayrıca, Liman alanında dört hatlı demiryolu terminali demiryolu taşımacılığını sağlamaktadır. Demiryolu terminalinde, dört demiryolu hattına eş zamanlı olarak ve manevra gerektirmeksizin yükleme ve tahliye operasyonu yapılabilmektedir. Beş rıhtıma demiryolu bağlantısı ile direkt olarak vagonlardan tahliye ve yükleme, direkt vagondan konteynere, konteynerden vagona iç dolum ve iç boşaltma hizmetleri verilmektedir [34]. Liman'a Konya ve Kayseri'den düzenli yük tren seferleri düzenlenmektedir. Mersin Limanı Ankara, Adana, Karaman, Konya, Kayseri, Gaziantep, Kahramanmaraş başta olmak üzere sanayi şehirlerine ve uluslararası tren istasyonlarına bağlantılıdır.

Geniş bir hinterlanda sahip olması; Limanların hinterlantları arka alanlarında var olan karayolu ve demiryolu bağlantıları ile sanayi tesisleri ile belirlenmektedir. Liman arka alanlarının gelişmişliği limanların yük hacmini etkilemekte ve yükün niteliğini belirlemektedir. Liman'a demiryolu, karayolu ve havayolu gibi çok modlu bağlantı mevcuttur.

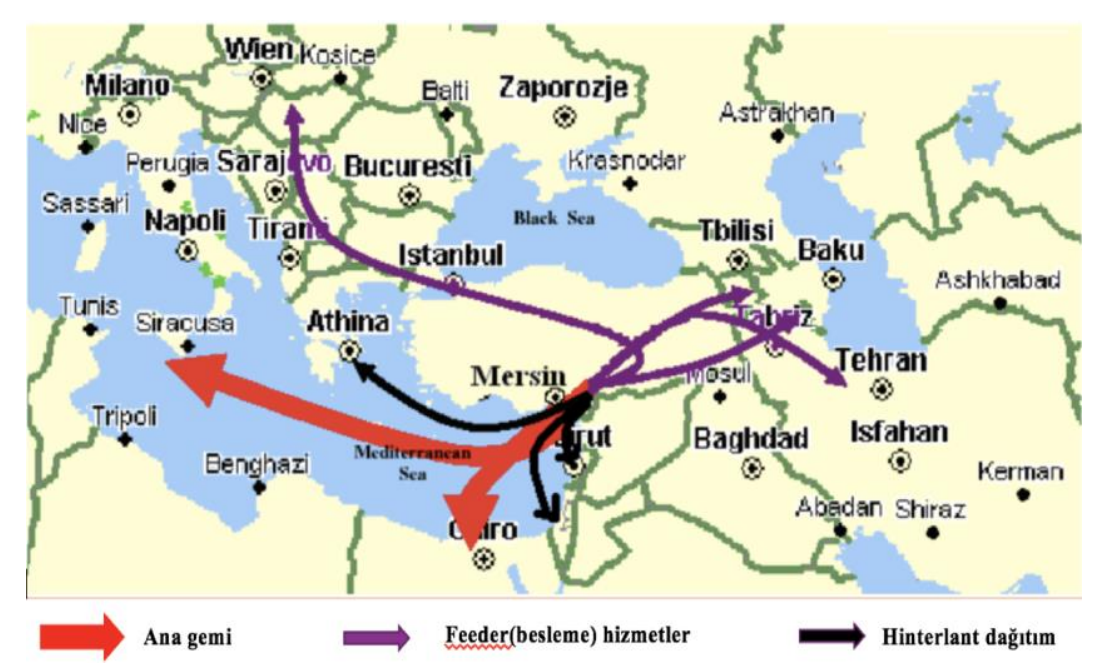

Şekil 3. Mersin Limanı deniz ve hinterlant bağlantıları [39]

Şekil 3’te görüldüğü gibi Mersin Limanı gerek deniz, gerekse hinterlant bağlantıları açısından oldukça iyi bir konumda bulunmaktadır. Mersin Limanı'nın hinterlandı daha çok yakın çevreyi kapsamaktadır. Liman'da elleçlenen toplam konteyner hacminin yaklaşık üçte biri Mersin ve Adana illerine dağıtılmakta, yaklaşık yarısı $300 \mathrm{~km}$ mesafe içindeki bölgelere gitmektedir [40]. Liman'dan İstanbul, Ankara ve İzmir gibi büyük şehirlere de konteyner akışı mevcuttur. Ayrıca, Akdeniz Bölgesi'nde diğer yakın konteyner limanları Assan Port ve Limak İskenderun ile hinterlant çakışması ve rekabeti söz konusudur [38]. Son yıllarda Kazakistan ve Azerbaycan ile hinterlant bağlantıları yoğunlaşmıştır. Dolayısıyla, Mersin Limanı Türkiye'de geniş hinterlanda hizmet veren liman olarak öne çıkmaktadır.

Demiryolu ağına göre geniş bir hinterlanda (etki alanına) sahip olması; Demiryolu ağına göre limanların hinterlandı Şekil 4'te yer almaktadır. Şekil'den de görüldüğü gibi limanların hinterlandları birbiriyle çakışmaktadır. Mersin Limanı'nın hinterlandı bölgedeki en yakın konteyner limanı olan ve demiryolu bağlantısı bulunan Limak İskenderun limanı ile büyük ölçüde çakışmaktadır.

Mersin limanı; demiryolu ağına göre Ankara, Adana, Hatay, Gaziantep, Kahramanmaraş, Konya, Aksaray, Kayseri, Karaman, Nevşehir, Niğde, Sivas, Kırşehir, Kilis ve Osmaniye illerini içeren 
geniş bir etki alanına sahiptir (Şekil 4). Öte yandan, Mersin Limanı transit bölge olarak Irak ve Suriye'ye, Kafkaslarda Azerbaycan, Orta Asya'da Kazakistan'a da hizmet vermektedir [34]. Ayrıca, Organize Sanayi Bölgeleri (OSB)'lere hizmet sunumu açısından Akdeniz Bölgesi'nde en geniş hizmet alanı Mersin Limanında görülmektedir. Mersin Limanı; Mersin, Adana, Konya, Aksaray, Niğde, Nevşehir, Kırşehir, Kayseri, Karaman, Kahramanmaraş, Sivas ve Diyarbakır illeri OSB'lerine hizmet sunmaktadır [38]. Bakü-Tiflis-Kars demiryolunun açılması ile demiryolu hinterlandı genişlemiş, Kazakistan ve Azerbaycan'dan demiryolu ile Mersin Limanı'na konteyner taşımacılığına başlanmıştır.

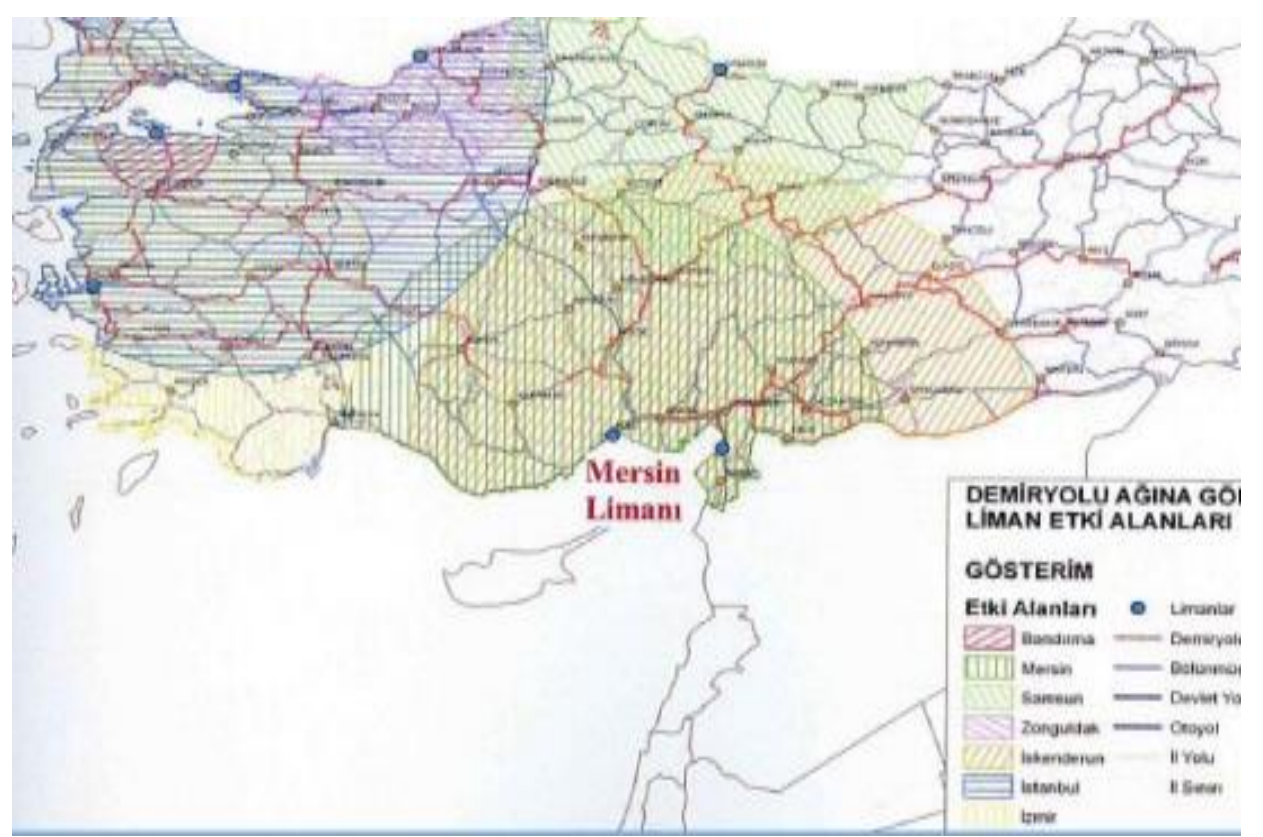

Şekil 4. Demiryolu ağına göre limanların hinterlandı (etki alanları) [22]

Limana bitişik bir serbest bölgenin bulunması: Mersin Limanı'na bitişik bir serbest bölgenin yer alması Liman'ın güçlü yönlerinden birini oluşturmaktadır. Mersin Serbest Bölge toplam brüt alanı $836.322 \mathrm{~m} 2$ 'dir ve Bölge'de 2018 y1lı sonu itibariyle firma sayıs1 433, istihdam sayısı ise 10.376'dır [41]. Mersin Limanı'nın serbest bölgeye yakınlığı yük trafiğini olumlu yönde etkilemekte ve yük sahiplerine zaman tasarrufu sağlamaktadır. Liman, serbest bölgeye koridor ile bağlanabilen Türkiye'deki tek limandır[34].

Küresel terminal operatörü PSA tarafından işletilmesi: 2007 yılına kadar Türkiye Cumhuriyeti Devlet Demiryolları (TCDD) tarafından işletilen Mersin Limanı'nın işletme hakkı, Özelleştirme İdaresi tarafindan 11 Mayıs 2007 tarihinde 36 yıl süreyle küresel terminal operatörü PSA(Port of Singapore Authority) ile Akfen Ortak Girişim Grubu tarafından kurulan Mersin Uluslararası Liman İşletmeciliği A.Ş. (MIP)'ye verilmiştir [34]. Küresel terminal operatörleri, küresel bir terminal ağı kurarak uluslararası terminal işletmeciliği yapan işletmelerdir [42]. Uzmanlıkları ve geniş pazarlama ağları ile limanların rekabet gücünü arttırmakta önemli rol oynamaktadırlar.

\subsection{Zaylf yönler}

Mersin Limanı'nın demiryolu hinterlant bağlantılarının geliştirilmesini olumsuz yönde etkileyen ve geliştirilmesi gereken zayıf yönler aşağıda sunulmuştur.

Mersin Limanından hinterlanda taşımaların karayolu ağırlıklı olması, demiryolu kullanımının yetersiz kalması: Mersin Limanı'ndan hinterlanda dış ticaret taşımalarında demiryolu kullanımı sadece \%3-4 civarındadır (Tablo 3). İhracat taşımalarında demiryolunun payının 2019 yılında 
\%5'leri aştığı, ithalat taşımalarında ise \% 2'lere kadar düştügü görülmektedir. Dolayısıyla ithalatç1ların demiryolunu daha az tercih ettiği söylenebilir.

Tablo 3. Mersin Limanı demiryolu hinterlant taşımaları $[35,43]$

\begin{tabular}{|c|c|c|c|c|c|c|c|c|c|}
\hline \multirow[b]{3}{*}{ Y1l } & \multicolumn{3}{|c|}{ İthalat (Boşaltma) } & \multicolumn{3}{|c|}{ İhracat (Yükleme) } & \multicolumn{3}{|c|}{ Toplam } \\
\hline & \multirow{2}{*}{$\begin{array}{l}\text { Limanda } \\
\text { Elleçlenen } \\
\text { ( Ton ) }\end{array}$} & \multicolumn{2}{|c|}{$\begin{array}{c}\text { Demiryolu } \\
\text { Taşıması } \\
\text { (Vagonla Giden) }\end{array}$} & \multirow{2}{*}{$\begin{array}{c}\text { Limanda } \\
\text { Elleçlenen } \\
\text { ( Ton ) }\end{array}$} & \multicolumn{2}{|c|}{$\begin{array}{c}\text { Demiryolu } \\
\text { Taşıması } \\
\text { (Vagonla Gelen) }\end{array}$} & \multirow{2}{*}{$\begin{array}{c}\text { Limanda } \\
\text { Elleçlenen } \\
\text { ( Ton ) }\end{array}$} & \multicolumn{2}{|c|}{$\begin{array}{c}\text { Demiryolu } \\
\text { Taşıması }\end{array}$} \\
\hline & & ( Ton ) & $\%$ & & ( Ton ) & $\%$ & & ( Ton ) & $\%$ \\
\hline 2019 & 19.005 .560 & 395.867 & 2,06 & 15.822 .960 & 820.207 & 5,18 & 34.828 .520 & 1.216 .074 & 3,49 \\
\hline 2020 & 18.767 .082 & 447.453 & 2,38 & 16.135 .054 & 744.582 & 4,61 & 34.902 .136 & 1.192 .035 & 3,42 \\
\hline
\end{tabular}

Demiryolu payının düşük kalmasında Mersin Limanı'nda elleçlenen toplam konteyner hacminin yaklaşık üçte birinin yakın mesafedeki Mersin ve Adana illerine dağıtılması, yaklaşık yarısının $300 \mathrm{~km}$ mesafe içindeki bölgelere gitmesi etken olabilir. Nitekim Adana ve Mersin arasındaki mesafe uzun olmadığı için, Adana'da bulunan müşterilerden Mersin Limanı'na demiryolu ile taşımacılık yapılmasına dair büyük bir talep gelmemektedir [14].

Demiryolu ve liman altyapı yatırımlarında yetersizlik ve koordinasyonsuzluk: İyi tasarlanmış liman hinterlandı demiryolu ya da karayolu sistemi tek başına yeterli değildir. Hinterland lojistiğini şekillendiren, limanla entegrasyon düzeyi ile birlikte ele alınan hinterlant taşımacılık sistemidir [44]. Bu nedenle, tedarik zinciri yaklaşımı ile yatırımların bütünsel yaklaşımla ele alınıp gerçekleştirilmesi gerekmektedir.

Mersin Limanı ile demiryolu ve lojistik şirketler arasında yetersiz iş birliği ve entegrasyon: Konteyner limanlarından demiryolu ile hinterlant taşımalarını arttırmakta başarılı olmuş Avrupa örnekleri incelendiğinde, bu başarıda mekik trenlerin kullanılması ve entegre fiyat uygulaması, demiryolu bağlantılarının geliştirilmesinde liman yönetimlerinin aktif rol alması, limanların demiryolu terminallerine ortak olması gibi stratejilerin önemli rol oynadığı görülmektedir. Ayrıca, işbirlikçi bir yönetim sistemi, kamu yatırımları ve kullanıcı taleplerinin karşılanması da önemli rol oynamıştır. Ancak, Türkiye'de bir lojistik merkez kurulurken liman ve demiryolu yönetimleri arasında yeterli işbirliği ve entegrasyonun sağlanamadığı, uluslararası lojistik zincirinde yer alan paydaşlar (liman ve demiryolu kuruluşları, lojistik şirketler, sanayiciler, ihracat ve ithalatçılar) arasında iş birliğinin yetersiz olduğu görülmektedir [45].

Yetersiz dijitalleşme: Fiziksel altyapı kapasitesini sürekli iyileştirme çalı̧̧malarına ek olarak dijitalleşmeye daha fazla önem verilerek bilginin etkin ve verimli bir şekilde işlenmesi, transferi ve paylaşımı önem taşımaktadır [44]. Dijitalizasyon, tedarik zincirinde aracıları azaltma, verilen hizmeti farklılaştırma, hizmetin düzeyini yükseltme, verimliliği arttırma ve işletme maliyetlerini düşürme olanağ 1 sunmaktadır. Demiryolu ve Mersin Limanında bu konudaki gelişim henüz yeterli değildir.

Liman içi yük elleçlemede rekabetin olmaması: Mersin Limanı konteyner terminali işletme hakk1 2007 yılında tek bir konsorsiyuma (PSA/Akfen) verilmiş ve Mersin limanı ölçeğinde birçok konteyner limanında bulunan farklı terminal operatörleri(örneğin Ambarlı) ile sağlanan liman içi rekabet sağlanamamıştır.

İstatistiklerin yetersizliği: Hinterlant taşımalarında taşıma türlerine göre istatistiklere ulaşmak oldukça zordur.

\subsection{Firsatlar}


Mersin Limanı'nın demiryolu hinterlant bağlantılarının geliştirilmesi için önemli firsatlar bulunmaktadir.

Doğu Akdeniz'den geçen konteyner trafiği: Türkiye, Asya-Avrupa deniz ticaret güzergâhına yakınlığı ile önemli bir stratejik konuma sahiptir. Akdeniz, binlerce yıldır önemli bir denizcilik ve ticaret rotası olmuştur. Akdeniz içi deniz ticaret akışları küresel trafik hacminin yaklaşık \%25'ini oluşturmaktadır [47]. Doğu Akdeniz ise, toplam küresel trafik hacminin yaklaşık \%5'ini ve Avrupa limanlarına yapılan deniz ticaret akışlarının yaklaşık \% 20'sini oluşturmaktadır[40].

Mersin Limanı da Türkiye'nin Doğu Akdeniz'deki en önemli konteyner limanıdır. Doğu Akdeniz Liman sistemi içinde merkezi bir konuma sahiptir. Sadece Pire ve Alexandria limanları Mersin Limanı'ndan daha merkezi konumda bulunmaktadır [40]. Doğu Akdeniz'deki bazı limanların aksine Mersin Limanı mevcut durumda bir aktarma limanı değildir. Ancak, Doğu Akdeniz'den geçen konteyner trafiği Mersin Limanı için önemli firsatlar yaratmaktadır.

Kuşak ve Yol Girişimi ile demiryollarının ve limanların desteklenmesi: Mersin Limanı'nın önemi Çin'in Kuşak ve Yol Girişimi ile daha da artmıştır. Çin Halk Cumhuriyeti Devlet Başkanı Xi Jinping tarafından 2013 yılında açıklanan Yeni İpek Yolu (OBOR), 2017 yılında Kuşak ve Yol (BRI) olarak yeniden adlandırılarak "İpek Yolu Ekonomi Kuşağı" ve "21. Yüzyıl Deniz İpek Yolu" girişimi altında hem karadan hem de denizden Doğu Asya, Orta Asya, Batı Asya, Afrika ve Avrupa'nın birbirine bağlanmasını hedeflemektedir. Çin, Kuşak ve Yol Girişimi ile Avrupa pazarına hem karadan hem denizden etkin şekilde ulaşabileceği bir ulaştırma altyapısı, ticaret ve yatırım bağlantısı kurmayı hedeflemektedir [48].

Orta Koridorun gelişmesi ve Bakü-Tiflis-Kars demiryolu hattının açılması: Başlangıcından itibaren Kuşak ve Yol Girişimini destekleyen Türkiye'nin konumu Çin - Avrupa güzergahında önemli bir kara bağlantısı olan 826 km uzunluğundaki Bakü-Tiflis-Kars demiryolunun 2017 yılında tek hat olarak dizel işletmeciliğe açılması ile güçlenmiştir. Kuşak ve Yol Girişiminin etkisi ile Avrupa ile Asya arasında demiryolu konteyner taşımacılığı canlanmış, özellikle Türkiye'nin desteklediği Orta Koridor, Bakü-Tiflis-Kars demiryolu hattının faaliyete başlaması ve 2019 tarihinde de Marmaray Boğaz Tüp Geçişinin yük trenlerine açılması ile taşıma süresi ve maliyetler açısından önemli bir rekabet avantajı elde etmiştir [40]. Orta Koridor, Çin'in Lianyungang Limanı'ndan başlayıp Kazakistan, Hazar Denizi, Azerbaycan, Gürcistan ve Türkiye'den geçerek Bakü-Tiflis-Kars demiryolu ile Avrupa'ya kadar uzanan çok modlu taşımacılık koridorudur [49]. Türkiye'nin ikinci büyük konteyner limanı olan Mersin Limanı da Orta Koridor hattına bağlanmakta, Orta Koridor'dan Mersin'e demiryolu ile konteyner taşımacılığı yapılmaktadır.

Tablo 4'te görüldüğü gibi Kazakistan'ın Kokhshetau, Kostenai ve Aktöbe şehirleri; Azerbaycan'ın Bakü şehri ile Mersin Limanı arasında konteyner trenleri çalışmaktadır. Mersin Limanı Bakü-Tiflis-Kars demiryolu hattından limanlara akacak yükler için güçlü bir alternatif oluşturmaktadır. Bakü-Tiflis-Kars demiryolu hattının, çift hat, elektrifikasyonlu, sinyalizasyonlu ve telekominikasyonlu olarak açıldığında yıllık 6,5 milyon ton yük taşıma kapasitesine ulaşması beklenmektedir [51].

Tablo 4. Orta Koridor'dan Mersin Limanı'na demiryolu ile konteyner taşıma güzergahı[50]

\begin{tabular}{cc}
\hline Güzergah & Mesafe $(\mathrm{km})$ \\
\hline Kokhshetau - Mersin & 4.700 \\
Kostenai- Mersin & 4.300 \\
Aktöbe- Mersin & 4.000 \\
Bakü - Mersin & 2.098 \\
\hline
\end{tabular}


Mersin Limanı hinterlandında demiryolu yatırımlarının devam etmesi: Mersin Limanı demiryolu hinterlandı, yapımı devam eden $423 \mathrm{~km}$. Konya-Karaman- Ulukışla (Niğde)- Yenice- Mersin Adana Hizlı Tren hattı ve $236 \mathrm{~km}$. Adana-Osmaniye- Gaziantep Hizlı Tren hattıyla desteklenecektir [50]. Söz konusu yatırım çalışmaları sona erdiğinde yük trenleri saatte $100 \mathrm{~km}$ hız yapabilecek, dolayısıyla taşıma süresi kısalacaktır.

Mersin Limanı yakınında Yenice'de lojistik merkez kurulması: Küresel lojistik zincirin bir parçası lojistik merkezler yükün toplanarak konsolide edildiği, diğer ulaşım türüne aktarma işleminin ve/veya katma değer faaliyetinin yapıldığ 1 ve yükün dağıtım sistemine aktarıldığ1 yerlerdir. Mersin Limanı'ndan hinterlanda taşımalarda demiryolu kullanımını arttırmak amacıyla Mersin ili içinde yer alan Yenice'de 510 dönüm arazi üzerine lojistik merkez kurulmuş ve işletmeye açılmıştır [51]. Mersin Limanına oldukça yakın olan lojistik merkez bünyesinde konteyner yükleme-boşaltma ve stok alanları, gümrük sahaları, tır otoparkı, tren teşkil, kabul ve sevk yolları, bakım onarım tesisleri ve müşteri ofisleri yer almaktadır. Lojistik ve liman hinterlant zincirinin önemli bir halkası olan lojistik merkezlerin gelişmesi, Mersin Limanının demiryolu bağlantılarının güçlendirilmesine önemli katkılar sağlayacaktır.

Demiryollarının serbestleştirilmesi: 01.05.2013 tarihli ve 28634 sayılı Resmi Gazete'de yayımlanan 6461 sayılı "Türkiye Demiryolu Ulaştırmasının Serbestleştirilmesi Hakkındaki Kanun" ile Türkiye'de demiryolu taşımacıllı̆g serbestleştirilerek özel sektörün de yük ve yolcu taşımacılığı yapmasının önü açılmıştır. Serbestleştirme, demiryolunun liman bağlantıları oluşturduğu Kayseri, Denizli, Aydın, Konya, Gaziantep gibi noktalardan Mersin Limanı'na daha fazla miktarda yükün, daha hızlı ve düzenli akmasını sağlayabilir.

Mersin Liman yönetiminin liman sahası içindeki demiryolu hattını büyütme hedefi: Mersin Limanı yönetimi liman sahası içindeki demiryolu hat kapasitesini liman içi yatırımlarla arttırmak amacındadır. Bu kapsamda, liman içindeki demiryolu hat sayısının 4'ten 6'ya, hat uzunluğunu ise 450 metreden 700 metreye çıkartmayı planlamaktadır [52]. Bu yatırımlar liman hinterlandında demiryolu taşımalarının artması için firsat yaratacaktır.

Sürdürülebilir taşımacılık stratejileri: Son yıllarda artan küresel ısınma ve getirdiği doğal afetler, taşımacılık sistemlerinin geliştirilmesi olgusuna ekonomik, sosyal ve çevresel hedefler arasında optimum dengeyi kurma amacını güden sürdürülebilirlik perspektifinden yaklaşılmaya başlandığı gözlenmektedir [48]. Müşterilerin çevreye duyarlılığı ve farkındalığı arttıkça karayolundan çevre dostu demiryoluna kayışlar olabilecektir

\subsection{Tehditler}

Mersin Limanı'nın demiryolu hinterlant bağlantılarının geliştirilmesi için tehdit oluşturan başlıca faktörler aşağıda sunulmuştur.

Bölgedeki güçlü rakip limanlar: Doğu Akdeniz, dünyanın en büyük konteyner limanlarına ev sahipliği yapmaktadır [36]. Dolayısı ile bölgede, Asya ülkelerinden gelen yük akışını çekmek için yoğun bir rekabet mevcuttur. Tablo 5'te görüldüğü gibi bölgenin en büyük konteyner limanı Yunanistan'ın Pire limanıdır. Listede Türkiye'den Ambarlı, Mersin ve İzmit limanları yer almaktadır.

Kuşak ve Yol Girişimi ile rakip limanların desteklenmesi: "Kuşak ve Yol Girişimi” kapsamında Çin'in denizcilik şirketi COSCO, 2009 yılında iki iskelesinin işletme hakkını aldığı Pire limanına yatırım yapmaya devam etmektedir [30]. Pire Limanı Akdeniz havzasının en büyük aktarma konteyner limanı haline gelmiştir. 
Küresel ekonomik krizler-COVID-19 Salgını: Küresel ekonomik krizler, ABD-Çin ticaret savaşları ve salgın hastalıklar dünya konteyner taşımalarını olumsuz etkilemektedir. COVID-19 salgını, denizcilik ağlarının, liman verimliliğinin ve Akdeniz'deki hinterlant bağlantısının kriz durumlarına karşı savunmasızlığını göstermiştir [47]. Denizcilik endüstrisi, uluslararası tedarik zincirlerinin sorunsuz işleyişinin hayati önem taşıyan bir aracı olarak ekolojik felaketler ve COVID-19 gibi salgınlar da dahil olmak üzere sürdürülebilirlik ve dayanıklılık oluşturmaya odaklanmalı, bunun yanı sıra küresel ölçekte uygulanabilir ve rekabetçi kalabilmek için verimliliği ve operasyonları geliştirmelidir.

Tablo 5. Başlıca Doğu Akdeniz Limanlarında konteyner trafiği (TEU) [36]

\begin{tabular}{cccccc}
\hline Liman & Ülke & 2018 & 2019 & Artı̧ \% & Sıra \\
\hline Mersin & Türkiye & 1.722 .000 & 1.854 .312 & 7,7 & 92 \\
Ambarlı & Türkiye & 3.194 .196 & 3.104 .882 & $-2,8$ & 55 \\
İzmit & Türkiye & 1.597 .620 & 1.715 .193 & 7,4 & 96 \\
Pire & Yunanistan & 4.907 .708 & 5.648 .000 & 15,1 & 26 \\
Port Said & Mısır & 3.105 .418 & 3.816 .084 & 22,9 & 46 \\
\hline
\end{tabular}

Müşterilerin demiryolu yük taşımacılığı kalite algısının düşük olması: Demiryolu taşımacılığına ilişkin sabit bir kalite standardının bulunmaması ve taşıma hızının düşük olması lojistik şirketlerin, ihracatçı ve üreticilerin demiryolunu tercih etmemelerine neden olmaktadır [48]. Bu algının düzeltilebilmesi için demiryolu yük taşımacılığında kalitenin arttırılması gerekmektedir.

Dijital lojistik ve akıllı limanlara yönelim: Yapay zeka, otomasyon, robot kullanımı ve daha birçok Endüstri 4.0 yeniliğinin lojistik, denizcilik ve diğer taşımacılık türlerine girmeye başladığ 1 gözlenmektedir. Pandeminin etkileri nedeniyle denizcilik sektörünün insansız operasyonlara daha fazla öncelik vermeye başlayacağı öngörülmektedir. Bu nedenle, rekabette üstün olabilmek için dijital lojistik ve akıllı liman uygulamalarının geliştirilmesi gerekmektedir [53, 54, 55, 56]. Aksi durum gelecekte önemli bir tehdit yaratabilecektir.

Bölgedeki politik ve güvenlik sorunları: Doğu Akdeniz, jeostratejik ve jeopolitik bakımdan çok eski tarihlerden bu yana gündemden hiç düşmeyen bir havzadır. Bu sorunlar lojistik süreçleri ve taşımacılığı etkileyen bir tehdit olarak karşımıza çıkmaktadır.

Nitelikli insan kaynağı ihtiyacı: Yakın gelecekte sektörün en büyük risklerinden olacak nitelikli insan kaynağı eksikliğinin, eğitim yoluyla kapatılmasına yönelik politikaların geliştirilmeli gerekmektedir [53].

Gümrüklerdeki sorunlar: Uluslararası lojistik zincirin önemli bir halkası olan gümrüklerde bekleme süreleri uzundur. Örneğin; Bakü-Tiflis-Kars demiryolu hattında büyük talep olmasına rağmen gümrük süreleri çok uzundur ve sadece Kars gümrüğünde konteynerlerin altı gün boyunca işlemler için bekletilmesi söz konusu olabilmektedir [46].

\section{Sonuç ve Öneriler}

Uluslararası ticarette liman-hinterlant bağlantılarının önem kazanmasının en önemli nedeni hinterlanda dağıtım maliyetinin toplam maliyetler içindeki yüksek payıdır. Bu nedenle, uluslararası ticaretten daha fazla pay alabilmek için rekabet halinde olan limanlar hem ekonomik hem de çevresel nedenlerle, demiryolu hinterlant bağlantılarını geliştirmeye yönelik önemli yatırımlar yapmaktadırlar. Avrupa'nın büyük konteyner limanlarında demiryolunun payının artmasında işbirlikçi bir yönetim sistemi, kamu yatırımları ve kullanıcı taleplerinin karşılanması önemli rol oynamıştır. 
$\mathrm{Bu}$ çalışmada, konteyner limanlarının demiryolu-hinterlant bağlantılarının geliştirilme potansiyeli, Mersin Limanı örnek alınarak SWOT analizi yöntemi ile incelenmiştir. SWOT analizi sonuçlarına göre; Türkiye'nin Doğu Akdeniz'deki en önemli konteyner limanı olan Mersin Limanı'na demiryolu bağlantısı ve Liman içinde demiryolu altyapısının mevcut olması çok olumlu bir faktör olarak karşımıza çıkmaktadır. Ayrıca, Mersin Limanı'nın geniş bir demiryolu hinterlandına sahip olması Liman'a güç katmaktadır. Bakü-Tiflis-Kars demiryolunun açılması ile demiryolu hinterlandı genişlemiş, Kazakistan ve Azerbaycan'dan demiryolu ile Mersin Limanı'na konteyner taşımacılığı yapılmaya başlanmıştır. Mersin Limanı'nın serbest bölgeye yakınlığı yük trafiğini olumlu yönde etkilemekte ve yük sahiplerine zaman tasarrufu sağlamaktadır. Liman'ın küresel konteyner terminal operatörü PSA tarafindan işletilmesi de uluslararası yüklerin limana çekilmesinde avantaj yaratmaktadır.

Ancak, Mersin Limanından hinterlanda taşımaların karayolu ağırlıklı olması ve demiryolu kullanımının yetersiz kalması en zayıf yönü oluşturmaktadır. Demiryolu taşımacılığı konusunda Türkiye'deki diğer limanlara göre daha avantajlı bir konumda olmasına rağmen Mersin Limanı'ndan hinterlanda taşımalarda demiryolu payının yıllar itibarıyla \%4'ü aşamadığı görülmektedir. Bu sonuçta, müşterilerin demiryolu kalite ve güvenilirlik algısının düşük olması yanında uluslararası lojistik zincirinde yer alan paydaşların (liman ve demiryolu kuruluşları, lojistik şirketler, sanayiciler, ihracat ve ithalatçılar) yeterli iş birliğini sağlayamamalarının da etkin olduğu söylenebilir.

Mersin Limanı'nın demiryolu-hinterlant bağlantılarını güçlendirmek için Çin'in Kuşak ve Yol Girişimi ile demiryollarını ve limanları desteklemesi, bu kapsamda Orta Koridorun gelişmesi ve Bakü-Tiflis-Kars demiryolu hattının açılması çok önemli firsatlar yaratmaktadır. Mersin Limanı'nın önemi Kuşak ve Yol Girişimi ile daha da artmıştır. Mersin Limanı Bakü-Tiflis-Kars demiryolu hattından limanlara akacak yükler için çok güçlü bir alternatif oluşturmaktadır. Öte yandan, Mersin Limanı'ndan hinterlanda taşımalarda demiryolu kullanımını arttırmak amacıyla Liman yakınında lojistik merkez kurulması ve Mersin Limanı hinterlandında demiryolu yatırımlarının devam etmesi önemli fırsatlar olarak değerlendirilmiştir. Ayrıca, Mersin Limanı yönetiminin liman sahası içinde demiryolu hattını genişletme planları da önemli bir fırsat yaratmaktadır.

Bölgede rakip limanların bulunması ve özellikle Pire Limanı'nın Kuşak ve Yol Girişimi ile desteklenmesi, küresel ekonomik krizler ve salgınlar ve müşterilerin demiryolu kalite algısının düşük olması, Mersin Limanı'nın demiryolu hinterlant bağlantılarını güçlendirilmesini etkileyecek önemli tehditler olarak karşımıza çıkmaktadır.

Bu çalışmada yapılan SWOT Analizi sonucunda belirlenen güçlü ve zayıf yönler alınacak önlemlerle dengelenebilir ancak sektörü doğrudan ya da dolaylı olarak etkileyen dışsal faktörleri oluşturan firsat ve tehditler önem taşımaktadır. Sektörün kontrolü dışında gelişen önemli tehditler arasında bölgedeki diğer limanlardan gelen rekabet, derinleşen küresel ekonomik kriz ve salgın nedeniyle denizyolu taşımacılığında yaşanan iptaller yer almaktadır.

İhracat odaklı bir kalkınma stratejisi uygulayan Türkiye'nin, uluslararası ticarette lojistik maliyetlerini azaltmak için liman-hinterlant bağlantılarının etkinliğine önem vermesi, trafiğin sürdürülebilir olmayan karayolundan demiryoluna kaydırılması, dolayısıyla hinterlanda taşımalarda demiryolu payının arttırılması gerekmektedir. Liman-hinterlant taşımalarında karayolu baskın rol oynasa da özellikle artan konteyner taşıması ve liman hinterlandının genişlemesi, demiryolu ile konteyner taşımacılığının önemini arttırmaktadır. Mersin Limanından hinterlanda taşımalarında demiryolu payını Barcelona limanı örneğindeki gibi, tedarik zinciri yaklaşımı ile uygulanacak stratejilerle arttırmak mümkündür. Hinterlantta stratejik yerlerde bulunan demiryolu tesislerine, lojistik merkezlere ortak yatırımlar ve mekik tren uygulamaları ile 
demiryolu kullanımı arttırılabilir. Bu stratejileri hayata geçirmek için en önemli konu, tedarik zincirinde yer alan tüm paydaşların (limanlar, demiryolu kuruluşları, lojistik şirketler, sanayiciler, ihracat ve ithalatçılar) iş birliği yaparak entegrasyonun sağlanmasıdır.

$\mathrm{Bu}$ çalışmada Mersin limanı-hinterlant taşıma maliyetleri dikkate alınmamıştır. LimanDemiryolu hinterlant taşıma maliyetleri ve lojistik maliyetleri de dikkate alınarak bir çalışmanın yapılması yararlı olacaktır.

\section{Teşekkür}

Değerli katkılarından ötürü Doç. Dr. Nur Jale Ece ve Fatih Yılmaz’a teşekkür ederim.

\section{Kaynakça}

[1] A. C. Trappa, I. Harris, V. S. Rodrigues and J. Sarkisa. "Maritime container shipping: Does coopetition improve cost and environmental efficiencies," Transportation Research Part D: Transport and Environment, vol. 87, pp. 102507, 2020.

[2] A. Amighini. China's new economic powerhouse. In. A. Amighini\& P. Magri (Eds.) China Champion of (Which) Globalisation (pp.613-37). Milano. Italy:ISPI. 2018.

[3] IMEAK DTO, "Sektör Raporu," 2019. [Online]. Available: https://ticaret.gov.tr/data/ 5d63d89d13b8762f7c43a738/16-Tasima\%20Sekillerine\% 20Gore\% 20Dis\%20Ticaret.pdf [Accessed November 29, 2020].

[4] V. Carbone and M. De Martino, "The changing role of ports in supply-chain management: an empirical analysis," Maritime Policy and Management, vol. 30, No 4, pp.305-320, 2003.

[5] R.Van den Berg and P.W.De Langen, "Hinterland strategies of port authorities: A case study of the port of Barcelona," Research in Transportation Economics, vol.33, pp.6-14, 2011.

[6] R. A. Halim, J. H. Kwakkel and L. A. Tavasszy, "A strategic model of port-hinterland freight distribution networks," Transportation Research Part E, vol.95, pp.368-384, 2016.

[7] T. Notteboom and J.P. Rodrigue, Re-assessingport-hinterland relationships in thecontext of global commodity chains. In:International Workshop on Ports. 2007.

[8] X. Shi and H.Li, "Developing the port hinterland: Different perspectives and theirapplication to Shenzhen Port, China," Research in Transportation Business \& Management, vol.19, pp. 42-50, 2016.

[9] U. Bucak and S. Esmer, "The Components of the port hinterland performance: A literature review study," Conference: III. Global Conference on Innovation in Marine Technology and the Future of Maritime Transportation, Selçuk,Izmir, Turkey, $18^{\text {th }}-19^{\text {th }}$ of April 2019.

[10] S. Özdemir, B. Keskin, T. Eren and E. Özcan, "Türkiye'deki lojistik merkezleri yatırım önceliklerinin değerlendirilmesinde çok kriterli karar modeli önerisi," Demiryolu Mühendisliği, vol. 12, pp.83-94, 2020.

[11] M. Bayhan, M. Türkmen and D. Kepe, "Denizli-Kaklık lojistik köyünün SWOT analizi ile değerlendirmesi," Mehmet Akif Ersoy Üniversitesi Sosyal Bilimler Enstitüsü Dergisi, vol. 9, no. 22, pp. 555-574, 2017.

[12] Ş. S. İrtem, "Limanların hinterlant bağlantı kabiliyetleri üzerine literatür taraması ve liman kapısı olarak Bucak Ovası," Burdur Mehmet Akif Ersoy Üniversitesi Oğuzhan Sosyal Bilimler Dergisi, vol. 1, no. 2, pp.117-137, 2019.

[13] H. Baran and Ç. Hitay, “İzmir Alsancak Limanı'nın etki alanı ve İzmir kentinin ekonomik yapısı ile bağı,", Dokuz Eylül Üniversitesi Denizcilik Fakültesi Dergisi, vol. 2, no. 2, pp. 67-81, 2010.

[14] Türkiye Cumhuriyeti Devlet Demiryolları (TCDD), TCDD Yük Pazar Araştırması Danışmanlık Hizmetleri Nihai Raporu, Aralık 2011.

[15] J. D. Müller, Transport policies for the Euro-Mediterranean Free-Trade Area: An agenda for multimodal transport reform in the Southern Mediterranean. World Bank Technical Paper, No 527. 2002.

[16] UNCTAD, Negotiations on transport and logistics services: Issues to consider. (UNCTAD/SDTE/TLB/2005/3), Geneva. 2006.

[17] T. Notteboom and J. P. Rodrigue, "Inland freight distribution and the sub- harborization of port terminals," First International Conference on Logistics Strategy for Ports, Dalian, China. 2004. 
[18] J. P. Rodrigue and T. Notteboom, "Dry ports in European and North American intermodal rail systems: Two of a kind," Research in Transportation Business and Management, vol. 5, pp.4-15 2012.

[19] H. Zeybek, "Ulaşım Sektöründe intermodalite ve lojistik alanındaki gelişmeler ve Türkiye’ye yansımaları," Doktora Tezi, Gazi Üniversitesi Sosyal Bilimler Enstitüsü, Ankara, 2007.

[20] O. Merk and T. Notteboom, Port hinterland connectivity. Discussion Paper No. 2015-13, OECD/ITF, 2015.

[21] R. A. Halim, J. H. Kwakkel and L. A. Tavasszy, "A scenario discovery study of the impact of uncertainties in the global container transport system on European ports," Futures, 2015.

[22] UBAK. Ulaştırma kıy yapıları master plan çalışması sonuç raporu. 2010.

[23] C. Ferrari, F. Parola and E. Gattorna, "Measuring the quality of port hinterland accessibility: the Ligurian case," Transport Policy, vol. 18, pp. 382-391, 2011.

[24] J. Monios and B. Lambert, "The heartland intermodal corridor: public-private partnerships and the transformation of institutional settings," Journal of Transport Geography, vol. 27 no. 1, pp.36-45, 2013.

[25] M. Acciaro and A. McKinnon, Efficient hinterland transport infrastructure and services for large container ports. Discussion Paper No. 2013-19. Prepared for the Roundtable on RT Port Investment and Container Shipping Markets Roundtable, 7-8 November 2013, Santiago, Chile. 2013.

[26] In, "Rail succesful modality for port of Gothenburg," published on 28-01-2020 [Online]. Available: www.railfreight.com [Accessed November 23, 2020].

[27] A. Woodburn, "An analysis of rail freight operational efficiency and mode share in the British porthinterland container market," Transportation Research Part D: Transport and Environment, vol. 51, pp. 190-202, 2017.

[28] Rotterdam Port. [Online]. Available: https://www.portofrotterdam.com/en/news-and-press-releases/ what-the-betuwe-route-has-brought-us-so-fa. [Accessed March 23, 2018].

[29] J-F. Arvis, V. Vesin, R. Carruthers, C. Ducruet and P. de Langen, Maritime Networks, Port Efficiency, and Hinterland Connectivity in the Mediterranean, International Bank for Reconstruction and Development / The World Bank, 2019.

[30] F. P. Van Der Putten(ed.), F. S. Montesano, J. van de Ven, and P. van Ham, The Geopolitical relevance of Piraeus and China's New Silk Road for Southeast Europe and Turkey. Clingendael Report, 2016.

[31] J. Jakóbowski, K. Popławski and M. Kaczmarski, The Silk Railroad. The EU-China rail connections: background, actors, interests. OSW studies, 72 Warsaw, 2018.

[32] Q. Zhang, W. Wang, Y. Peng, and Z. Guo, "Impact of rail transport services on port competition based on a spatial duopoly model," Ocean \& Coastal Management, vol. 148, pp. 113-130, 2017.

[33] In, "Mersin Limanı" [Online]. Available: https://tr.wikipedia.org/wiki/Mersin_Liman\%C4\%B1\#/media/Dosya:Port_of_Mersin_(MIP).jpg [Accessed December 26, 2020].

[34] Mersin Port [Online]. Available: https://www.mersinport.com.tr [Accessed December 02, 2020].

[35] Ulaştırma ve Altyapı Bakanlığg (UAB) Denizcilik Genel Müdürlüğü (2021). Denizcilik İstatistikleri - Konteyner İstatistikleri. [Online]. Available: https://denizcilikistatistikleri.uab.gov.tr/konteyneristatistik. [Accessed March 08, 2021].

[36] In, "Lloyd's List One Hundred Ports", December, 2020. [Online]. Available: https://lloydslist.maritimeintelligence.informa.com/one-hundred-container-ports-2020 [Accessed December 27, 2020].

[37] E. Gürel and M. Tat, "SWOT analysis: A theoretical review," The Journal of International Social Research, vol. 10 no. 51, 2017.

[38] AYGM, Limanlar geri saha karayolu ve demiryolu bağlantıları master plan çalışması sonuç raporu, 2015.

[39] H. Zeybek and M. Kaynak, "What role for Turkish ports in the regional logistics supply chains?," The International Conference on Information Systems, Logistics and Supply Chain (ILS International Conference), Madison-Wisconsin, USA, 2008.

[40] O. Merk and O. Bagis, The competitiveness of global port-cities: the case of Mersin-Turkey. OECD Regional Development Working Papers, 2013/01, OECD Publishing. 2013.

[41] Mersin Serbest Bölgesi, [Online]. Available: www.mtso.org.tr [Accessed November 20, 2020].

[42] S.Esmer, [Online]. Available: https://www.lojistikhatti.com/haber/2017/06/kuresel-terminaloperatorleri-icin-turkiyenin-onemi-ve-obor-ulastirma-stratejisi [Accessed March 09, 2021].

[43] TCDD, Liman ve Feribot Yönetimi Dairesi Başkanlığı, 2021. 
[44] R.Bergqvist, Hinterland Logistics and Global Supply Chain, In. D-W Song \& P. Panayides (Eds.) In book: Maritime Logistics - A Guide to Contemporary Shipping and Port ManagementEdition: 2nd edition Publisher: Kogan Page, 2015.

[45] M. Kaynak and H. Zeybek, "İntermodal terminallerin gelişiminde lojistik merkezler, dağıtım parkları ve Türkiye'deki durum,” Gazi Üniversitesi İktisadi ve İdari Bilimler Fakültesi Dergisi, vol. 9, no. 2, pp. 39-58, 2007.

[46] TUSİAD, Türkiye-Çin ekonomik ilişkileri sektörel yuvarlak masa toplantıları, 4 October 2019.

[47] UFM Webinars, 27 May 2020, [Online]. Available: https://ufmsecretariat.org/impacts-covid-portsmaritime-transport-mediterranean/ [Accessed October 18, 2020].

[48] H. Zeybek, "Uluslararası Ticarette Yeni Avrasya Ulaşım Yolları Arayışı: Demiryolu Yük Taşımacılığına Etkileri,” Avrasya Etüdleri, pp.135-154, 2019.

[49] H. Zeybek, "Yeni İpek Yolunun kıtalar arası demiryolu konteyner taşımacılığına etkisi: PESTLE analizi," Ömer Halisdemir Üniversitesi İktisadi ve İdari Bilimler Fakültesi Dergisi, vol. 13, no. 4, pp.724-740, 2020. DOI: 10.25287/ohuiibf.709425

[50] Ulaştırma ve Altyapı Bakanlığı https://www.uab.gov.tr/uploads/pages/butce-sunumu/2021-butce-sunumu.pdf [Accessed December 13, 2020].

[51] Ulaştırma ve Altyapı Bakanlığı (UAB), Ulaşan ve erişen Türkiye. Ankara, 2020

[52] In, "MIP Katalog" [Online]. Available: https://www.mersinport.com.tr/pdf/MIP_katalog Mayis_2018.pdf [Accessed December 03, 2020].

[53] ÖİK, Lojistik hizmetlerin geliştirilmesi özel ihtisas komisyonu raporu, On Birinci Kalkınma Planı (2019-2023), T.C. Kalkınma Bakanlığı, Ankara,2018.

[54] S. Özdemir, B. Keskin, T. Eren and E. Özcan, “Türkiye'deki lojistik merkezleri yatırım önceliklerinin değerlendirilmesinde çok kriterli karar modeli önerisi," Demiryolu Mühendisliği, no. 12, pp. 83-94, July. 2020. doi: 10.47072/demiryolu.722626

[55] M. Nalçakan, "A research on externalities in transportation sector,” Demiryolu Mühendisliği, no. 12, pp. 95-105, July. 2020. doi: 10.47072/demiryolu.740115

[56] S. Özdemir, Ö. Sacar, E. Özcan, "Dijkstra algoritması kullanılarak ipek yolu koridorları arasında en kısa ulaştırma güzergâhının belirlenmesi," Demiryolu Mühendisliği, no. 13, pp. 97-105, Jan. 2021. doi: 10.47072/demiryolu.811572

\section{Özgeçmiş}

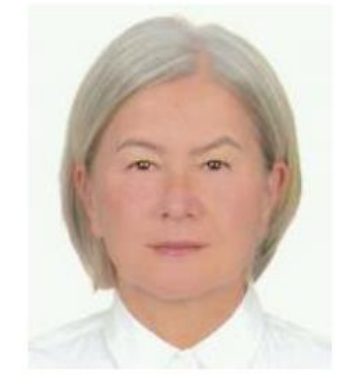

\section{Beyanlar:}

Bu makalede bilimsel araştırma ve yayın etiğine uyulmuştur.

\section{Hülya ZEYBEK}

1984 yılında Ankara Üniversitesi Siyasal Bilgiler Fakültesi İşletme Bölümünü bitirmiştir. 1989 yılında aynı üniversitede yüksek lisansını, 2007 yılında ise Gazi Üniversitesinde doktorasını tamamlamıştır. 1985-1989 döneminde Başbakanlık Hazine ve Dış Ticaret Müsteşarlığ İhracatı Geliştirme Etüd Merkezinde (İGEME), 19892013 döneminde TCDD Genel Müdürlüğünde çalışmış, 2013 yılında emekli olmuştur. Halen Eskişehir Teknik Üniversitesi Ulaştırma MYO'da konuk öğretim elemanı olarak görev yapmaktadır.

E-Posta: hulyazeybek@eskisehir.edu.tr 